\title{
The Research on Course of Database Development Based on .NET
}

\author{
Kun LIU, Wenliang NIU*, Tingmei WANG \\ College of Applied Science and Technology, Beijing Union University, Beijing, China
}

\begin{abstract}
Based on the task of WinForm programer, this paper explores the post positioning of the course "Database Developmeng Based on .NET" in higher vacational colleges. According to the specific teaching cases, we put forward the project-driven and case-driven design scheme so as to train students' job skills to competent for the tasks. We analyse this scheme from the aspects of course oritentation, teachning objectives, teaching content, teaching methods, teaching process, evalution methods and ect.
\end{abstract}

KEYWORD: Task-driven; Teaching method; Database development; .NET

\section{INTRODUCTION}

"Database Development Based on .NET" is a strong practical course that teaches how to develop database program using c\# language. We design this course using task-driven teaching method which not only impart knowledges, train programming skills but also cultivate students' thinking ability. "Task-driven" is one of constructivism theory teaching mode that new knowledges are included in one or several tasks[1,2]. Students discuss and analyze the proposed tasks, extract knowledges involved in the tasks, figure out new knowledges and old knowledges, find out the methods to solve the problems with the help and guidance of teachers and learn all the knowledges by achieving all the tasks finally. For teachers, we focus on task-driven. For students we focus on thinking ability and the combination of learn and practice[3]. Considering the higher vocational students' characteristics, new knowledges must be blent in tasks and taught by teacher rather than by students' self-learning or discussion. After students master the new knowledges, they can try to accomplish the tasks. In this process, students can not only review old knowledges, but also practice and consolidate the new knowledges.

\section{DESIGN CONCEPT}

(1)We change the traditional theory teaching mode and use the method of teaching theoretical knowledge in practice. This method will put dull theory into the specific project, and realize the idear of learning by doing, doing by learning, teaching by doing, practicing by teaching.

(2)It is the key point of the reform that training profession ablility is set as the target and company station is set as the guide. We choose the teaching content according to industry's needs.

(3)Each project team is made by several students to complete the project. The whole procedure simulate the real work environment of enterprise, So students can exerience the real working situation.

(4)The tradition mode of teacher speak, students listen is displaced by the learner-centered teching method. We do not confine students' learning only to schoolwork and pay more attention to students selflearning ability

(5)We attach importance to the cooperation with enterprises and listen to the industry, so the contents and methods suit to the need of the industy well.

The design concept of this course is shown in Figure 1.

\section{COURSE CONTENT}

The course content is made of a project which has four versions and some little cases. The project is divided into many tasks.

We use "Books Management System" throughout the teaching process in the course of "Database Development Based on .NET". This system has four versions and the latter improves the former by adding new functions or using new knowledges, so students can learn new knowledges gradually. The realization of this whole system is divided into several tasks and each task has basic part and 
advanced part. All the students must complete basic part and the top students try to complete advanced part. Students are encouraged to design tasks that teacher hasn't present and complete more functions.

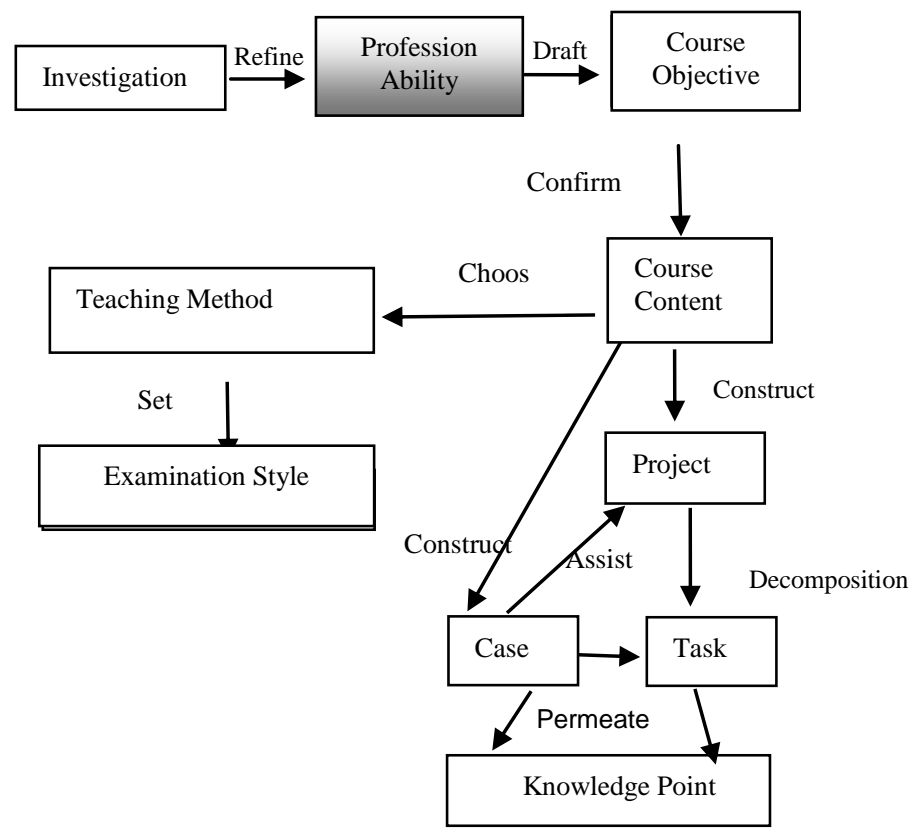

Figure 1. Design Concept

The design and realization of "Book Management System" is the process of decomposing tasks constantly. The system consists of login module, books management module, users management module, administrators management module, borrowing and lending books module and etc. As shown in Figure 2, the modules without underlines are basic modules that must be finished, and the modules with underlines are advanced modules for top students. Students can present other tasks and achieve more functions. Each module can be divided into tasks.

(1)Books management module

Tasks in this module include add books, edit books, inquire books, delete books and etc. Students can also present other tasks. Add books task mainly involves insert operation, edit books task mainly involves update operation, delete books mainly involves delete operation and inquire books mainly involves select operation. Inquire module can be inquiring by category, inquiring by books' name, inquiring all books, inquiring books borrowed and etc. All tasks in this module are completed with the guidance of teacher. The knowledges cover insert, delete, update and select operation in the database development. After students master the new knowledges by accomplishing the tasks in this module, they can finish the tasks in other modules by themselves or by discussing with each other.

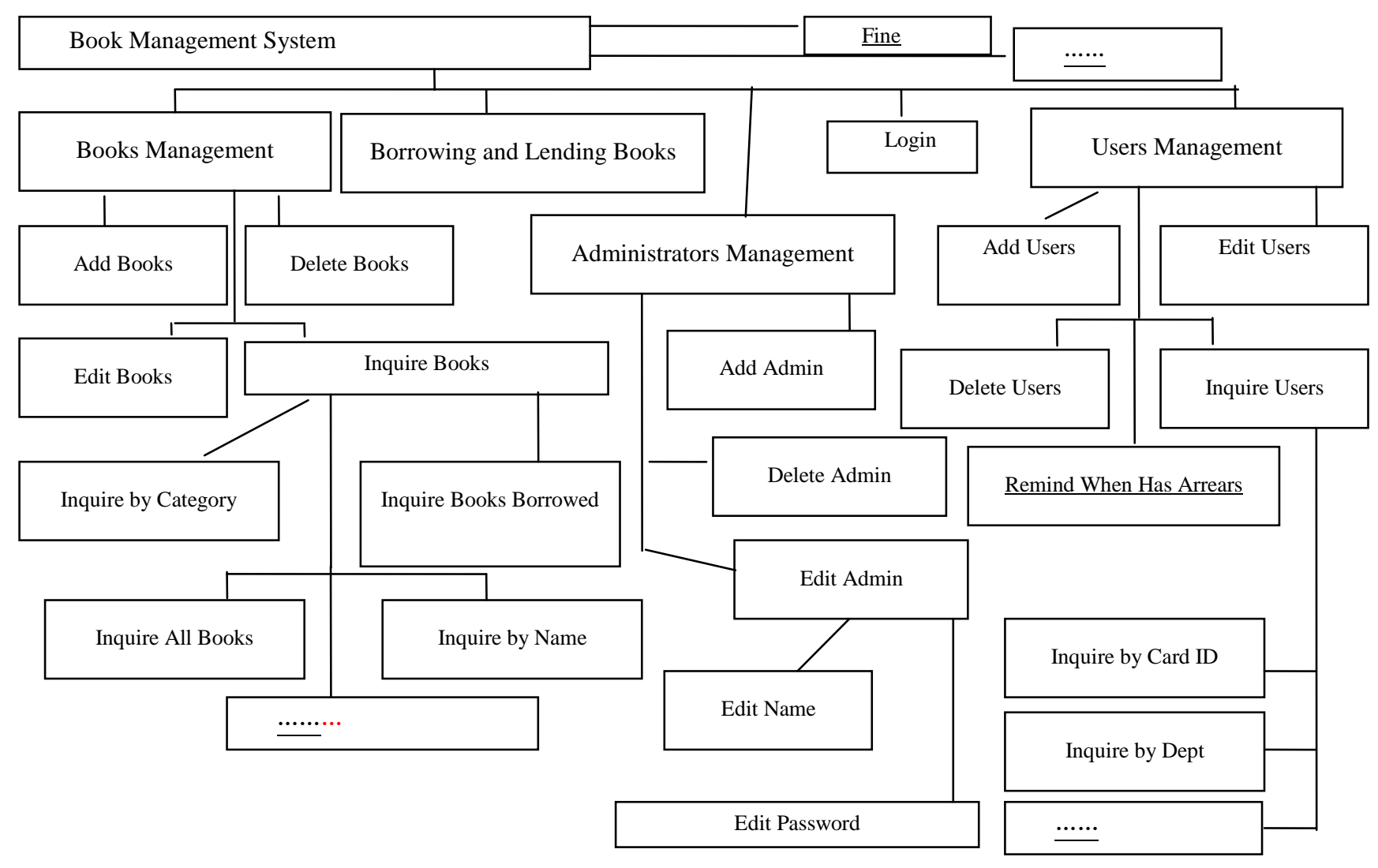

Figure 2. System Basic Function

(2)User management module

Tasks in this module are accomplished by students themselves. They can use the knowledges learned in the books management module. Tasks in this module includes inquire users, add users, delete users, edit users and etc.

(3)Administrator management module

Tasks in this module include add administrators, 
delete administrators, edit administrators and etc. Students finish these tasks by themselves. They can display their ability to achieve more tasks.

(4)Borrowing and lending books module

This module includes borrowing books and lending books. Students finish these tasks with the help of teacher. The operations involved in this module are select, insert, delete and update.

(5)Login module

Teacher teaches the tasks in this module. Users of different types have different privileges. Administrator can undertake all operations and normal users can only undertake inquiring operations.

(6)Other modules

Top students can present and accomplish other tasks that not involved in Figure 2.

"Book Manager System" used in this course has four versions. The first is basic version which involves database design, inquire, add, update, and delete operations. Each module has one or several tasks.

Table 1. Operation-Task Table

\begin{tabular}{|c|c|c|}
\hline Operation & Knowledge points & Tasks Involved \\
\hline $\begin{array}{l}\text { Database } \\
\text { Design }\end{array}$ & $\begin{array}{l}\text { Database basic knowledges } \\
\text { Sql statement } \\
\text { SQL Server } 2005 \text { Tool }\end{array}$ & Designing database \\
\hline Inquire & $\begin{array}{l}\text { Select statement } \\
\text { ADO.Net objects: } \\
\text { Connection, Command, } \\
\text { DataReader, DataAdapter } \\
\text { ADO.Net DataSet } \\
\text { component } \\
\text { Data display method: } \\
\text { DataGridView component } \\
\text { Select with parameters }\end{array}$ & $\begin{array}{l}\text { Inquire books } \\
\text { Inquire users } \\
\text { Login } \\
\text { Borrow books } \\
\text { Lend books } \\
\text { Remind When Has } \\
\text { Arrears } \\
\underline{\text { Fine....... }}\end{array}$ \\
\hline Add & $\begin{array}{l}\text { Add statement } \\
\text { Command object } \\
\text { Add records } \\
\text { Add with parameters }\end{array}$ & $\begin{array}{l}\text { Add books } \\
\text { Add users } \\
\text { Add administrator } \\
\text { Borrow books } \\
\text { Lend books } \\
\text { Fine...... } \\
\end{array}$ \\
\hline Update & $\begin{array}{l}\text { Update statement } \\
\text { Command object } \\
\text { Update records } \\
\text { Update with parameters }\end{array}$ & $\begin{array}{l}\text { Edit books } \\
\text { Edit users } \\
\text { Edit administrator } \\
\text { Borrow books } \\
\text { Lend books } \\
\ldots \ldots \\
\end{array}$ \\
\hline Delete & $\begin{array}{l}\text { Delete statement } \\
\text { Command object } \\
\text { Delete records } \\
\text { Delete with parameters }\end{array}$ & $\begin{array}{l}\text { Delete books } \\
\text { Delete users } \\
\text { Delete administrator } \\
\text { Borrow books } \\
\text { Lend books } \\
\text { Fine...... }\end{array}$ \\
\hline
\end{tabular}

The knowledge points or tasks listed in the table 1 are achieved in the basic version of the system. The knowledges consist of old knowledges and new knowledges. We adopt the means of inspiring by teacher, reviewing or exercising by students and etc to learn old knowledges. For new knowledge, we adopt means of teaching by teacher and exercising by students. Students accomplish the basic system by autonomous learning, cooperative learning, teacher's lectures and other means. As shown in Table 1, the tasks without underline are tasks must be done and the tasks with underline are optional. The italics tasks are accomplished by students themselves.

Table 2. Versions of the system

\begin{tabular}{|l|l|l|}
\hline Versions & Teaching Contents & Tasks \\
\hline Version 1 & $\begin{array}{l}\text { Basic knowledges of } \\
\text { developing database } \\
\text { program using C\# }\end{array}$ & As shown in Table 1 \\
\hline Version 2 & Stored procedure & Realizing stored procedure \\
\hline Version 3 & Crystal report & Realizing crystal report \\
\hline Version 4 & MVC & $\begin{array}{l}\text { Realizing MVC design } \\
\text { pattern }\end{array}$ \\
\hline
\end{tabular}

After students finishing the first version, they have mastered the basic knowledges. The second version introduces stored procedure. The teacher explains the concept of stored procedure, and how to use stored procedure in the program. Then students rewrite all the SQL statements in the first version using stored procedure. The third version introduces crystal report. We accomplish the system using MVC design pattern in the last version. As shown in Table 2 , the teaching process always uses the same system. We apply new knowledges in the system after learning the new knowledges and consummate the system gradually, so that we can avoid redesigning program each time.

\section{TEACHING METHOD}

The course cites engineering project as the main line, Actual projects as the carrier and The cultivation of the comprehensive vocational ability for vocational and technical college students should be carried out throughout the entire process of education.

The experimental teaching mode includes three types as knowledge teaching, simple case development and comprehensive project development. After teaching some new knowledge, students study these new knowledge by each experiment. A case development includes a series of knowledge and students finish a comprehensive project after some chapters.

So for each knowledge point, the teaching mode is "knowing - teaching - practicing - case development -- reviewing - project development......" The students can master knowledge more firmly by the recycling process can.

(1)Technology----In this course, students will experience a large number of computer training, code reading, code correction, normalization checking, so students' programming skill and normative will be improved. 
(2)Experience----Through the completion of a large number of actual projects, students' software project development experience will be improved.

(3)Professional quality----Each student will have a roll in the project and each member must collaborate together to finish the project. So students will form good professional habits.

\section{EXAMINATION STYLE}

Students introspect the process of solving the problems and appraise with each other or by themselves. The teacher makes comments suitably and helps students to make summarization. When students have finished a task, the teacher shows and appraises several students' works rather than gives a score to evaluate students' works[4].

The discussion sections are scheduled for evaluating after finishing each task in "Books Management System"[5]. Firstly, each group presents their works and explains the module function realized. Secondly, other students make queries or propose improvement measures. Finally, teacher comments the works, attaches attention to the works that can be learned and points out the place need to be improved. By analyzing and evaluating, teacher confirms students' perfect places and points out some defects. Doing these not only stimulates students' enthusiasm and confidence, but also makes students understand the pricinple of live and learn. Students' quality can also be promoted.

For each project, the evaluation includes six aspects process as analysis process, implementation process, implementation result, attitude, creativity, team cooperation. The proportion as shown in Table3.

Table 3. Examination Value

\begin{tabular}{|l|l|}
\hline Content & Value \\
\hline Analysis process & $10 \%$ \\
\hline Implementation process & $30 \%$ \\
\hline Implementation result & $20 \%$ \\
\hline Attitude & $20 \%$ \\
\hline Creativity & $10 \%$ \\
\hline Team cooperation & $10 \%$ \\
\hline
\end{tabular}

\section{CONCLUSION}

"Database Development Based on .NET" course is a strong practical, highly creative course. The taskdriven teaching method provides a way to learn knowledge from the elementary to profound, from outward appearance to inner essence, so that students can learn new knowledges and skills step by step.

In this course, we use task-driven method to launch teaching activity under the driven of each typical mission. By using the "Teacher-Teaching, Student-Exploring, Cooperation-Learning" mode, teacher guides students step by step, from simple to complex, from easy to difficult, to accomplish series of tasks

\section{ACKNOWLEDGMENTS}

The study is subsidized by Electronic Information Engineering Professional Higher Vacational Education Undergraduate Personnel Training Mode Reform, Funding Project for Academic Human Resources Development in Beijing Union University and Funding Project of Competence Development Program for Beijing VET Teachers.

\section{REFERENCES}

[1] Huang Xiao-dong, He Kui. Practice of Research Teaching of Specialized Courese for Higher Education of Engineer. China Educational Technique \& Equipment, 2012-2.

[2] Fu Shen-wen, Liu Yu-rong. Discusses Shallowly the Task Driven is Applied in Teaching "Analog Electronic Technique". Journal of Guangdong AIB Polytechnic College, 2010-11.

[3] Cong Peili. Explore Task-Driven Approach. China Educational Technique \& Equipment, 2011-3.

[4] Yang Jihong, Kong Yonghong. Research on "Behavior oriented, Task - based" Teaching Mode. Journal of Shanxi adio \& TV University, 2011-1.

[5] Wang Si, Yang Dong-yun,et. Research on practice assignment-driven teaching pattern based on the recognition law. Science-Technology and Management, 2011-1. 